Al-Huquq: Journal of Indonesian Islamic Economic Law, 3 (2), 2021: 163 - 184

ISSN: 2715-0003; E-ISSN 2714-5514

DOI: http://doi.org/10.19105/alhuquq.v3i2.4834

\title{
Implikasi Hukum bagi Nasabah Perbankan Syariah yang Beragama Islam dalam Menyelesaikan Sengketa di Pengadilan Negeri
}

\author{
Harya Galih \\ (Fakultas Hukum Universitas Brawijaya, Jl. Veteran, Ketawanggede, Lowokwaru, \\ Kota Malang, 65145)
}

\begin{abstract}
Abstrak:
Tujuan dari penelitian ini adalah untuk menerapkan tentang implikasi hukum bagi nasabah perbankan syariah yang beragama Islam dalam memutuskan sengketa perbankan syariah di pengadilan negeri. Metode yang diterapkan dalam penelitian ini adalah adalah yuridis normatif. Sehingga penelitian ini menelaah tentang kepastian hukum kewenangan instansi peradilan dalam menyelesaikan urusan sengketa perbankan syariah. Hasil dari penelitian ini berupa implikasi hukum bagi nasabah perbankan syariah yang beragama islam dalam menyelesaikan sengketa perbankan syariah di Pengadilan Negeri yaitu terdiri dari implikasi terhadap Putusan Mahkamah Konstitusi Nomor 93/PUU-X/2012 yang menimbulkan kekosongan hukum (vacumrecht) dan norma kabur, kekaburan Norma yang menimbulkan ketidakpastian hukum untuk menyelesaikan sengketa perbankan syariah, dan dapat menguatkan kedudukan dan eksistensi Peradilan Agama dalam penyelesaian sengketa perbankan syariah, sekaligus menutup peluang ditempuhnya penyelesaian sengketa perbankan syariah melalui instansi Peradilan Umum. (The purpose of this study is to apply the legal implications for Islamic banking customers who are Muslim in deciding Islamic banking disputes in district courts. The method applied in this research is normative juridical. Thus, this study examines the legal certainty of the judicial authorities in resolving disputes over islamic banking after the Constitutional Court Decision Number 93/PUU-X/2012. The results of this study are in the form of legal implications for Islamic banking customers who are Muslim in resolving islamic banking disputes in the District Court, which consist of implications for the Constitutional Court Decision Number 93/PUU-X/2012 which creates a legal vacuum (vacumrecht) and vague norms, Norms ambiguity that

email koresproden harya.galih@gmail.com

https://creativecommons.org/licenses/by-nc/4.0/

Copyright (c) 2019 by al-huquq. All Right Reserved
\end{abstract}


creates legal uncertainty for resolving islamic banking disputes, and can strengthen the position and existence of the Religious Courts in resolving islamic banking disputes, as well as closing the opportunity for islamic banking dispute resolution through the General Courts.

\section{Kata Kunci:}

Implikasi Hukum, Perbankan Syariah, Nasabah, Sengketa, Pengadilan Negeri

\section{Pendahuluan}

Bank muamalat merupakan perbankan syariah pertama di Indonesia yakni pada tahun 1992. Kehadiran Bank Muamalat Indonesia terbentuk karena terdapat Undang-Undang Nomor 7 Tahun 1992 tentang Perbankan ${ }^{1}$. Terdapat perbankan syariah di Indonesia tidak hanya berimbas terdapat pembaharuan peraturan perundang-undangan didalam bidang perbankan syariah, tetapi juga brimplikasi pada peraturan perundang-undangan yang mengatur institusi lainnya, satu diantaranya yakni instansi peradilan. ${ }^{2}$

Keberadaan Bank Muamalat Indonesia memudahkan kehidupan khalayak, khususnya bagi umat Islam yang ingin melakukan transaksi tanpa riba, seperti halnya diatur dalam bank konvensional, bank muamalat merupakan bank umum syariah pertama yang menghadirkan kerangka pembagian manfaat yang unik dan berbeda dengan bank biasa, sistem perbankan yang dikenal orang-orang Indonesia. Bank Islam didirikan dengan niat penuh untuk memajukan dan mendorong penerapan dasar-dasar syariah dalam Islam untuk transaksi keuangan dan perbankan dan kegiatan terkait lainnya. ${ }^{3}$

\footnotetext{
1 UU Nomor 10 Tahun 1998, “Undang-Undang Republik Indonesia Nomor 7 Tahun 1992 Tentang Perbankan Sebagaimana Telah Diubah Dengan Undang-Undang Nomor 10 Tahun 1998," Bank Indonesia, 1998.

2 Andrew Shandy Utama, "PERKEMBANGAN PERBANKAN SYARIAH DI INDONESIA," UNES Law Review, 2020, https://doi.org/10.31933/unesrev.v2i3.121.

3 ZUBAIDAH NASUTION and SHOLIKHA OKTAVI, "ANALISIS FAKTORFAKTOR YANG MEMPENGARUHI KINERJA KEUANGAN PERBANKAN DI INDONESIA," JURNAL MASHARIF AL-SYARIAH, 2016.
} 
Implikasi Hukum bagi Nasabah Perbankan Syariah yang Beragama Islam dalam Menyelesaikan Sengketa di Pengadilan Negeri

Peraturan baru ini menyebabkan ekspansi yang signifikan atas industri perbankan syariah nasional dan sekaligus menandai pengakuan Bank Indonesia atas keberadaan bank syriah dalam sistem dual bank. Hal tersebut menjadi satu diantara batu loncatan bagi terbentuknya suatu aturan tersendiri mengenai Perbankan syariah, guna menopang dan menjadi underlying bagi implementasi sistem Perbankan yang mengaplikasikan sistem Hukum Islam yang tentunya berbeda dengan ketetapan yang dianut oleh Perbankan Konvensional, sehingga dirasa sangat perlu untuk dibentuk suatu instrumen regulasi tersendiri.

Pada tahun 2002, Bank Indonesia merevisi aturan yang berkaitan dengan unit usaha syariah dengan mengadopsi Peraturan Bank Indonesia No. 9/19/ PBI/2007 mengenai Perubahan Kegiatan Bank Umum Biasa Menjadi Bank Umum Berdasarkan Dasar Syariah dan Pembukaan Cabang Bank berdasarkan dasar syariah, bank umum biasa, mengatur: 1) transformasi bank biasa menjadi bank sejalan hukum islam; 2) transformasi cabang biasa menjadi cabang syariah; 3) Transformasi mesin kasir biasa menjadi cabang syariah; 4) Membuka bab-bab syariah di bab-bab biasa; dan 5) pembukaan unit syariah di kantor reguler.

Ketetapan di atas merupakan satu instrumen yang telah terbentuk untuk mendukung perkembangan sistem perbankan yang sejalan dengan ajaran syariah Islam, dan masih terdapat instrumeninstrumen lain yang menjadi cikal bakal terbentuknya suatu regulasi pasti dan konkret yang menjadi dasar dalam sistem perbankan syariah di Indonesia. Sampai dengan pada tanggal 16 Juli 2008, sistem perbankan di Indonesia menemui era baru. UU Perbankan Syariah yang masuk ke Dewan Perwakilan Rakyat (DPR) sejak pertengahan 2005 sebagai RUU Inisiatif DPR telah disahkan sehingga Peraturan Perbankan Syariah kini resmi berlaku di Indonesia yaitu UU Nomor 21 Tahun 2008 mengenai Perbankan Syariah.

Perbankan syariah tidak mengenal unsur yang terkandung dalam perbankan konvensional yakni riba. Selain riba, dalam sistem perbankan syariah mengharamkan unsur maisir, gharar, haram, dan zalim dalam pola perekonomiannya. Perbankan syariah memiliki kekhususan dalam hal praktik perbankan jika dibandingkan dengan perbankan konvensional. Bank syariah dalam menjalankan kegiatan 
komersialnya tidak didasarkan pada bunga, tetapi pada sistem pembagian keuntungan untuk keuntungan atau kerugian. ${ }^{4}$

Ketetapan tersebut yang menjadi perdebatan di khalayak, baik bagi para akademisi maupun para praktisi perbankan syariah, karena menurut mereka terdapat dualisme instansi litigasi (choice of forum) yang berwenang untuk menangani sengketa perbankan syariah antar para pihak yang beragama Islam, yang mana dapat melalui Peradilan Agama maupun Peradilan Umum, dalam hal ini Peradilan Negeri. Hal tersebut yang kemudian memicu terdapat uji materi ke Mahkamah Konstitusi, yang mana Pemohon Uji Materi menganggap bahwa keberlakuan ketetapan Pasal 55 ayat (2) dan (3) UU Nomor 21 Tahun 2008 tidak mempunyai kepastian hukum (legal uncertainty) apabila dilihat dari sudut pandang formil dan yang dijadikan dasar pengujiannya yakni Pasal 28D ayat (1) UUD 1945 yang berbunyi, "Setiap orang berhak atas pengakuan, jaminan, perlindungan, dan kepastian hukum yang adil serta perlakuan yang sama di hadapan hukum." 5

Dalam hal ini, pemohon berpandangan bahwa atas ketetapan Pasal 55 ayat (2) dan (3) tidak secara lugas menentukan peradilan mana yang harus dipakai bila terjadi sengketa syariah antar pihak yang beragama Islam karena terdapat kebebasan memilih (choice of forum) yang memicu berbagai penafsiran mengenai peradilan yang dipilih atau yang diperjanjikan oleh tiap-tiap pihak yang terkait sehingga memicu ketidaktetapan hukum. Jika para pihak yang saling bersengketa memiliki agama yang non Islam, maka wajar jika permasalahan tersebut dibawa keranah Pengadilan Negeri. Di samping itu, di dalam Pasal 55 ayat (1) mengatur secara lugas untuk sengketa perbankan syariah harus diselesaikan melalui Peradilan Agama.

Dalam hal ini, masalahnya bukan saja pada hakim Pengadilan Negeri yang belum tentu memahami problematika ekonomi syariah ${ }^{6}$

\footnotetext{
4 M. Rifqinizamy Karsayuda, "Politik Hukum Nasional Legislasi Hukum Ekonomi Syariah," Journal de Jure, 2016, https:// doi.org/10.18860/j-fsh.v7i1.3510.

5 Made Warka and Erie Hariyanto, "Kedudukan Bank Syariah Dalam Sistem Perbankan Di Indonesia," IQTISHADIA: Jurnal Ekonomi \& Perbankan Syariah, 2016, https://doi.org/10.19105/iqtishadia.v3i2.1076.

${ }^{6}$ A M Isnaeni, "Standar Hukum Sistem Syariah Pada Lembaga Keuangan Bukan Bank Dalam Bentuk Asuransi Syariah," Jurnal Unizar Law Review, 2019.
} 
Implikasi Hukum bagi Nasabah Perbankan Syariah yang Beragama Islam dalam Menyelesaikan Sengketa di Pengadilan Negeri

Namun terlebih lagi, Peradilan Umum tidak mengaplikasikan hukum Islam sebagai dasar hukum untuk mengadili konflik-konflik yang dimaksud. ${ }^{7}$

Dalam konteks Pasal 55 UU Perbankan Syariah walaupaun pasca Putusan MK, tetap menyerahkan peluang tafsir untuk memilih menangani sengketa untuk mengaplikasikan instansi peradilan tertentu. Sedangkan di Pasal/Ayat atau bahkan UU lainnya (Pasal $49^{8}$ secara nyata menentukan sistem peradilan mana yang harus digunakan, terutama bagi umat Islam, hal ini akan memicu penafsiran yang berbeda dari pihak yang berbeda, terlebih lagi, ayat lain menyiratkan bahwa dalam hal ini dasar-dasar Syariah harus dihormati, sehingga menciptakan ketidaktetapan hukum. Hal ini disebabkan karena setiap lingkungan peradilan hanya memiliki yurisdiksi terbatas untuk menangani konflik yang diserahkan oleh UU, sejalan dengan kompetensi absolut dalam konteks peradilan, seperti halnya diatur dalam UU No. 48 Tahun 2009 mengenai Kehakiman. ${ }^{9}$

Yang terjadi di khalayak seperti halnya disebut di atas dalam beberapa kasus pasca putusan MK tersebut menampilkan bahwa terjadi penafsiran yang berbeda mengenai makna kepastian hukum penyelesaian sengketa perbankan Syariah terutama bagi para pihak yang beragama Islam. Dalam konteks ini ditunjukkan melalui perbedaan penafsiran antara kubu pemerintah dengan kubu pemohon yang disampaikan pada saat proses Judicial Review seperti halnya tercatat dalam PMK No. 93/PUU-X/ 2012.

Namun kembali kepada 10 yang hanya menghapuskan penjabaran Pasal 55 ayat (2) UU Nomor 21 Tahun 2008, memicu pertanyaan-pertanyaan menarik yang secara teori hukum memerlukan pengkajian komprehensif mengenai ketidakjelasan akan keberlakuan dan implementasi dari Pasal 55 ayat (2). Keberlakuan Pasal 55 ayat (2) dengan demikian masih memiliki potensi akan

\footnotetext{
${ }^{7}$ M. S. I Antonio, Bank Syariah: Dari Teori Ke Praktik (Jakarta: Gema Insani, 2001).

8 UU Republik Indonesia Nomor 3 Tahun 2006 Mengenai Perubahan Atas UU Nomor 7 Tahun 1989 Mengenai Peradilan Agama)

9 Fadly Andrianto, "Kepastian Hukum Dalam Politik Hukum Di Indonesia," Administrative Law and Governance Journal, 2020, https://doi.org/10.14710/alj.v3i1.114-123.

10 Putusan Mahkamah Konstitusi Nomor 93/PUU-X/2012
} 
terdapat ketidaktetapan hukum atas kekuatan hukum dari AkadAkad yang telah atau akan terbentuk dan berlaku bagi para pelaku perbankan syariah dan pihak terkait lainnya. ${ }^{11}$

Pasal 1 angka 4 Peraturan Mahkamah Agung Nomor 14 Tahun 2016 mengenai Tata cara Penyelesaian Konflik Ekonomi Syariah, Isu perbankan syariah masuk dalam ranah urusan ekonomi syariah. Yang dimaksud dengan ekonomi syariah yakni yang bergerak di bidang ekonomi syariah, antara lain bank syariah, instansi keuangan mikro syariah, asuransi syariah, reasuransi syariah, reksa dana syariah, obligasi syariah, surat berharga berjangka syariah, surat berharga syariah, pembiayaan syariah, pegadaian syariah, dana pensiun syariah, instansi keuangan Bisnis syariah, termasuk wakaf, infak dan shadao, yang bersifat komersial, baik kontroversial maupun sukarela. ${ }^{12}$ Ekonomi syariah merupakan satu diantara bidang di mana pengadilan agama dituntut dan diberdayakan untuk mengadili, memutus, dan menangani konflik pada tingkat pertama. ${ }^{13}$ Pengadilan yang berwenang menangani sengketa keredit macet pada bank syraiah (perbankan syariah) yakni Pengadilan Agama.

Dalam konteks inilah riset ini memusatkan kajian secara teoritik mengenai fenomena hukum tersebut dalam sudut pandang ratio legis atau alasan dan tujuan umum dan kewenangan. Oleh sebab itu, riset ini dilaksanakan untuk mendapatkan kejelasan, titik terang, serta proyeksi mengenai logika dalam penyelesaian sengketa yang dimana para pihaknya semua beragama Islam dalam sengketa perbankan syariah. Oleh karenanya, diangkatlah riset dengan judul "Implikasi Hukum Bagi Nasabah Perbankan Syariah yang Beragama Islam Dalam Menangani Sengketa Perbankan Syariah di Pengadilan Negeri."

\footnotetext{
11 E Kencanawati, "POLITIK HUKUM TERHADAP PENYELESAIAN SENGKETA EKONOMI SYARIAH DALAM PEMBANGUNAN HUKUM NASIONAL INDONESIA," Jurnal Paradigma Hukum Pembangunan, 2017.

12 Dian Febriyani and Ida Mursidah, "Ekonomi Dan Perbankan Syariah Di Tengah Era Digital," Hukum Ekonomi Syariah, 2020.

13 UU Republik Indonesia Nomor 3 Tahun 2006 Mengenai Perubahan Atas UU Nomor 7 Tahun 1989 Mengenai Peradilan Agama
} 
Implikasi Hukum bagi Nasabah Perbankan Syariah yang Beragama Islam dalam Menyelesaikan Sengketa di Pengadilan Negeri

\section{Metode Penelitian}

Jenis penelitian yang digunakan dalam penelitian ini adalah normatif. Penelitian hukum normatif merupakan penelitian hukum yang dilakukan dengan cara meneliti bahan Pustaka atau data sekunder. ${ }^{14}$ Menurut Peter Mahmud Marzuki, penelitian hukum normatif adalah suatu proses untuk menemukan suatu aturan hukum, prinsip-prinsip hukkum, maupun doktrin-doktrin hukum guna menjawab isu hukum yang dihadapi. ${ }^{15}$

Pendekatan yang digunakan dalam riset ini yakni pendektakan perundang-undangan. Menurut Soerjono Soekanto, pendekatan perundang-undangan yakni riset hukum yang dilaksanakan dengan cara menelaah bahan pustaka atau data sekunder sebagai dasar riset dengan menelusuri peraturan dan kepustakaan yang berkaitan dengan problematika yang diteliti ${ }^{16}$.

Sejalan dengan metode riset yang digunakan tersebut yakni untuk menelaah kepastian hukum kewenangan instansi peradilan dalam penyelesaian sengketa perbankan syariah pasca 17 , sehingga menyerahkan kemanfaatan dan kepastian hukum serta titik terang bagi khalayak dan pihak yang berkepentingan.

\section{Implikasi terhadap Putusan Mahkamah Konstitusi Nomor 93/PUU- X/2012 yang Menimbulkan Kekosongan Hukum (vacumrecht) dan Norma Kabur}

Hukum Perbankan (Banking Law) merupakan hukum yang mengaatur mengenai perbankan, instansi, kegiatan komersial, cara dan proses melakukan kegiatan perbankan. satu diantara fungsi utama dari bank yakni menghimpun serta menyalurkan dana masayarakat. Artinya akan membahas mengenai peraturan hukum (legal regulation) dan asas hukum, struktur hukum serta budaya hukum yang mangatur hal-hal yang berhubungan dengan bank.

\footnotetext{
14 Jonaedi Efendi and Johnny Ibrahim, Metode Penelitian Hukum Normatif Dan Empiris, Kencana, 2018.

15 Bismar Nasution, "Metode Penelitian Hukum Normatif Dan Perbandingan Hukum," in Dialog Interaktif Tentang Penelitian Hukum Dan Hasil Penulisan Hukum Pada Majalah Akreditasi (Fakultas Hukum Universitas Sumatera Utara, Medan, 2003).

${ }^{16}$ Kornelius Benuf and Muhamad Azhar, "Metodologi Penelitian Hukum Sebagai Instrumen Mengurai Permasalahan Hukum Kontemporer," Jurnal Gema Keadilan 3, no. 2 (2019): 145-60.

17 Putusan Mahkamah Konstitusi Nomor 93/PUU-X/2012
} 
Definis dari bank yang dikemukakan oleh para ekonom semuanya hampir sama atau hanya dalam Bahasa yang berbeda atau arti yang berbeda. Definisi atau pengertian bank menurut buku "Bank Dan Instansi Keuangan Lainnya" 18 Perbankan dirancang untuk mendorong tercapainya pembangunan negeri dalam rangka peningkatan pemerataan, pertumbuhan ekonomi dan stabilitas nasional guna meningkatkan kesejahteraan rakyat.

Bank syariah merupakan bank yang menerapkan dasar dan kaidah islam dalam menjalankan operasionalnya. Seperti bank umum lainnya, bank syariah juga memiliki fungsi sebagai intermediasi. Bank memiliki fungsi sebagai mediasi yang dirancang untuk menghimpun dana dan mengirimkannya kepada manyarakatt yang membutuhkan dana. Satu diantara metode perbankan syariah untuk mengumpulkan aset dari khalayak umum yakni dengan mendapatkan aset sebagai simpanan dan menyebarkannya kepada individu yang membutuhkan aset sebagai kredit. ${ }^{19}$

Perbankan syariah berjalan sebagai intermediasi perantara moneter antara unit moneter yang memiliki cadangan berlimpah dan unit berbeda yang membutuhkan cadangan. Dengan demikian, demi menjalankan fungsi tersebut maka instansi perbankan syariah akan membuat kegiatan komersial dalam bentuk penggalangan dana, penyaluran dana dan penyediaan berbagai layanan bagi khalayak untuk transaksi keuangan. ${ }^{20}$

Satu diantara fungsi intermediasi perbankan syariah yakni sebagai instansi penyalur dana kepada khalayak sebagai bentuk pinjaman. Perkreditan dalam Undang-Undang Nomor 21 Tahun 2008 tentang Perbankan Syariah (selanjutnya disebut UU Perbankan Syariah) dicirikan sebagai hubungan sah yang muncul antara pemegang utang (nasabah) dan pemberi pinjaman (bank), yaitu: hasil yang sah sebagai hak dan komitmen. Satu diantara komitmen peminjam yakni melakukan angsuran dan mengembalikan pembiayaan yang diserahkan oleh pemberi pinjaman. Dalam hal

18 Toto Prihadi, “Analisis Laporan Keuangan,” in Analisis Laporan Keuangan, 2020.

19 Manduh M. Hanafi dan Abdul Halim, "Tujuan Analisis Laporan Keuangan," Analisis Laporan Keuangan, 2016.

${ }^{20}$ Mardani, Aspek Hukum Lembaga Keuangan Syariah Di Indonesia, Kencana, 2017. 
Implikasi Hukum bagi Nasabah Perbankan Syariah yang Beragama Islam dalam Menyelesaikan Sengketa di Pengadilan Negeri

peminjam lalai untuk memenuhi komitmennya, perdebatan akan diselesaikan sejalan dengan Pasal 55 UU Perbankan Syariah.

Dalam 21 mengenai pengaplikasian dasar syariah dalam kegiatan penghimpunan dana dan penyaluran dana serta pelayanan jasa bank syariah seperti halnya telah diubah dengan PBI NO.10/16/PBI/ 2008, menyatakan bahwa yang sebelumnya terjadi jika satu diantara pihak tidak memenuhi komitmennya yang ditentukan dalam kesepahaman antara bank dan nasabah, atau jika ada pertanyaan antara bank dan nasabah, penyelesaiannya dibantu melalui musyawarah. Kedua, jika pembicaraan tidak menghasilkan kesepahaman, maka perdebatan dapat diselesaikan antara lain melalui intervensi, termasuk intermediasi perbankan, sejalan UU. Ketiga, jika tidak tercapai kesepakatan dalam penyelesaian problematika seperti halnya dimaksud pada ayat (2), maka perdebatan dapat diselesaikan melalui instrumen asersi sejalan hukum islam atau melalui badan hukum yang bergantung pada peraturan perUUan yang berlaku. ${ }^{22}$

Dengan demikian penyelesaian sengketa Perbankan Syariah menurut Bank Indonesia seperti halnya tertuang dalam ${ }^{23}$ diharapkan penyelesaiannya melalui konsultasi dan intermediasi perbankan. Jika perkembangan ini tidak tercapai, perdebatan dapat diselesaikan melalui instrumen diskresi syariah atau melalui badan hukum sejalan dengan peraturan perUUan yang berlaku.

Dalam pasal 55 Adapun tujuan pada ayat (1) mengungkapkan bahwa pertanyaan yang terkait dengan perbankan syariah diselesaikan melalui pengadilan yang ketat ${ }^{24}$. Ayat (2) menjabarkan bahwa jika pertemuan telah menyepakati tujuan debat selain seperti halnya disinggung pada ayat (1), penyelesaian pertanyaan selesai sejalan dengan substansi Akad. Ayat (3) menjabarkan bahwa tujuan pertanyaan seperti halnya disinggung pada ayat (2) tidak boleh bermengenaian dengan standar syariah. Dalam klarifikasi Pasal 55, tujuan perdebatan yang diselesaikan sejalan substansi perjanjian yakni melalui pengaturan, intersesi perbankan melalui Badan

21 Peraturan Bank Indonesia Nomor 9/19/PBI/2007

22 (Peraturan Bank Indonesia Nomor 9/19/PBI/2007)

23 Peraturan Bank Indonesia Nomor 9/19/PBI/2007

24 UU Nomor 21 Tahun 2008 
Arbitrase Syariah Nasional (Basyarnas) atau instansi mediasi lainnya; serta melalui pengadilan umum). ${ }^{25}$

Pasal 55 UU Perbankan Syariah yang diidentikkan dengan penyelesaian perdebatan Perbankan Syariah diselesaikan melalui 2 (dua) pengadilan, yaitu Pengadilan Agama dan Pengadilan Negeri, namun dalam Pasal 55 UU Perbankan Syariah terdapat pedomanpedoman yang diidentikkan dengan Syariah. Pertanyaan perbankan Dalam Pasal 55 ayat (1) UU Perbankan Syariah terlihat bahwa tujuan pertanyaan mengenai perbankan syariah diselesaikan melalui pengadilan yang lugas. Ini menyiratkan menampilkan bahwa pengadilan yang ketat memiliki kemampuan tertinggi untuk mendengar dan memilih contoh bank syariah. Hal ini sejalan dengan pengaturan yang terdapat dalam Pasal 59 huruf (I) UU Peradilan Agama.

Pasal 55 ayat (2) UU Perbankan Sejalan hukum islam, menyatakan bahwa jika para pihak tidak menginginkan penyelesaian sengketa dipengadian agama, maka pada saat itu penyelesaian harus diubah sejalan dengan substansi hukum persetujuan. Akad digunakan sebagai alasan untuk mempersoalkan tujuan dalam perbankan syariah dengan alasan bahwa dalam hukum perjanjian, kesepakan antara para pihak akan menjadi akad (istilah dalam perbankan sejalan hukum islam) ${ }^{26}$. Jika perjanjian disepakati oleh para pihak, maka perjanjian itu menjadi hukum bagi orang-orang yang membuatnya. Artinya, seluruh substansi pasal, termasuk halhal yang berkaitan dengan sengketa dalam perjanjian kontaktual yang disepakati dalam musyawarah, akan mengikat kedua pelaku (untuk situasi ini ada pihak perbankan syariah dengan nasabahnya).

Penyelesaian sejalan kesepakatan seperti halnya dimaksud dalam Pasal 55 ayat (2) UU Perbankan Syaariah ini, dapat diselesaikan dengan 2 (dua) cara, yaitu tujuan debat melalui pengadilan dan di luar pengadilan. Isu dalam pembicaraan ini yakni titik dimana penyelesaian perdebatan perbankan diselesaikan melalui pengadilan (settlement in court). Seharusnya berbahaya mengingat Pasal 55 ayat (2) UU Perbankan Syariah menyerahkan

\footnotetext{
25 UU Nomor 21 Tahun 2008)

26 Fikri Al-Haq Fachryana, "Manajemen Risiko Strategis Bank Syariah," Jurnal Manajemen, Ekonomi, Keuangan Dan Akuntansi, 2020.
} 
Implikasi Hukum bagi Nasabah Perbankan Syariah yang Beragama Islam dalam Menyelesaikan Sengketa di Pengadilan Negeri

kesempatan kepada majelis untuk menetapkannya di Pengadilan Negeri. ${ }^{27}$

Sehubungan dengan terdapat Pasal 55 ayat (2) tersebut, diperkirakan terdapat peraturan perundang-undangan yang bertentangan atau meliputi peraturan perundang-undangan yang terkait dengan penyelesaian sengketa Perbankan Syaraiah. Pasal 55 ayat (1) penyelesaian perdebatan Perbankan Sejalan hukum islam diselesaikan di dalam Peradilan Agama, namun kembali Pasal 55 ayat (2) menyerahkan kesempatan kepada Pengadilan Negeri untuk memutuskan persoalan Perbankan Syariah ${ }^{28}$. Karena mencakup UU dan pedoman, diperkirakan bahwa pedoman yang berkaitan dengan penyelesaian problematika perbankan syariah tidak dapat menyerahkan keyakinan yang sah atas pihak. Meliputi UU-undang dan pedoman juga dapat menyerahkan keputusan hukum kepada para pihak, sehingga bertentangan dengan Pasal 28D ayat $1 .{ }^{29}$ Satu diantara hal yang diamanatkan oleh Pasal 28D ayat (1) tersebut yakni setiap warga negara berhak untuk mendapatkan jaminan kepastian hukum.

Kepastian peraturan yakni ketika peratuan ditulis dan diterbitkan dengan penuh keyakinan karena mengatur secara jelas dan logis. Dapat dimengerti dalam arti tidak diragukan (multitafsir) dan logis. Hal ini dimaklumi dan menjadi norma, sehingga tidak bertentangan dan tidak memicu konflik norma. Kepastian hukum memiliki acuan pada penerapan hukum yang jelas, tetap, dan konsisten, yang pengaplikasiannya tidak dapat dipicu oleh keadaan subjektif. Keyakinan dan keadilan bukan saja persyaratan moral, tetapi karakteristik faktual dari hukum. ${ }^{30}$

Menurut Utrecht, Kepastian hukum memiliki dua arti, yaitu: pertama, terdapat aturan umum yang memungkinkan khalayak mengetahui tindakan apa yang boleh atau tidak boleh dilaksanakan, dan kedua, berupa perlindungan hukum atas individu dari

\footnotetext{
27 Indra Syafii and Isnaini Harahap, "Peluang Perbankan Syariah Di Indonesia," Seminar Nasional Teknologi Komputer E Sains (SAINTEKS), 2020.

${ }^{28}$ Halil Khusairi, "Hukum Perbankan Syariah," Al-Qisthu: Jurnal Kajian Ilmu-Ilmu Hukum, 2015, https://doi.org/10.32694/010120.

${ }^{29}$ Undang Undang Dasar Negara Republik Indonesia Tahun 1945

30 Jonaed Efendi, Kamus Istilah Hukum Populer, Cet. Ke-I, Jakarta, Predana Media Group, 2016.
} 
kesewenang-wenangan pemerintah, karena dalam terdapat aturan umum, orang dapat mengetahui segala sesuatu yang dapat dipaksakan atau diterapkan oleh negara dalam hubungannya dengan individu. ${ }^{31}$

Kekaburan Norma yang Menimbulkan Ketidakpastian Hukum untuk Menyelesaikan Sengketa Perbankan Sejalan hukum islam

Satu di antara penyelesaian sengketa Perbankan Syariah yakni melalui Peradilan Umum, yaitu Pengadilan Negeri bagi nasabah perbankan syariah yang beragama islam, seperti halnya yang telah di jabarkan diatas, kewenangan yang diserahkan oleh UU Perbankan Syariah kepada Peradilan Umum ini membuat terdapat tumpang tindih kewenangan absolut antara dua badan peradilan, yaitu Pengadilan Agama dengan Pengadilan Negeri. Berdasarkan hal tersebut maka Mahkamah Kontitusi dirasa perlu untuk menguji materiil Penjabaran Pasal 55 ayat (2) huruf (d) UU Perbankan Syariah tersebut. Akan tetapi dalam putusannya Mahkamah Konsitusi justru menganulir seluruh penjabaran Pasal 55 ayat (2) UU Perbankan Syariah ini, Hal ini memicu problematika baru, yaitu terdapat ambiguitas hukum. Ambiguitas hukum ini dapat mengakibatkan tidak tercapainya kepastian hukum dalam penyelesaian sengketa di perbankan syariah, terutama dalam penyelesaian sengketa melalui jalur non-litigasi.

Implikasi hukum pada Putusan Mahkamah Konstitusi Nomor 93/PUU-X/2012 apa yang menyebabkan ambiguitas norma, dapat memicu ketidaktetapan hukum bagi penyelesaian sengketa bank syariah. Berdasarkan ketetapan di atas, maka dapat diketahui bahwa putusan 32 atas penyelesaian sengketa perbankan syariah memiliki implikasi hukum berupa perproblematikaan hukum baru berupa tidak terdapat kepastian hukum bagi para pihak yang akan menangani sengketa perbankan syariah melalui jalur non yudisial. Jika dikaitkan dengan teori kepastian hukum Jan Miklael Otto, penyelesaian sengketa yang melibatkan bank syariah, apalagi tanpa litigasi, nampaknya belum mampu menyerahkan kepastian hukum. Kepastian hukum menurut Jan Michael Otto lebih berdimensi hukum

\footnotetext{
31 Asdi Marni, Edi Darmawijaya, and Faisal Fauzan, “Jurnal Kajian Ilmu Hukum Dan Syariah," Jurnal PETITA, 2018.

32 Mahkamah Konstitusi Nomor 93/PUU-X/2012
} 
Implikasi Hukum bagi Nasabah Perbankan Syariah yang Beragama Islam dalam Menyelesaikan Sengketa di Pengadilan Negeri

dan menyerahkan batasan kepastian hukum dengan unsur-unsur sebagai berikut ${ }^{33}$ :

1. Ada ketetapan hukum yang nyata, konsisten, tersedia, dipublikasikan, dan diakui pemerintah;

2. Warga kebanyakan menyesuaikan perilakunya sejalan dengan aturan yang berlaku;

3. Hakim yudisial yang mandiri, tidak memihak dalam hal keabsahan dan konsisten dalam menangani sengketa secara tuntas; dan

4. Keputusan hakim secara kongkret dilaksanakan.

Berdasarkan pembahasan terkait implikasi hukum pada Putusan Mahkamah Konstitusi Nomor 93/PUU-X/2012, berbagai pandangan seputar polemik tidak terdapat kepastian hukum dalam Pasal 55 ayat (2) dan (3) UU 21/2008 mengenai Perbankan Syariah di atas, kita dapat menyimpulkan bahwa ada dua pandangan yang berbeda, yang tiap-tiap bersikeras mempertahankan pandangannya dengan argumennya sendiri.

Penilaian utama yang disampaikan oleh para Pemohon, ahli Pemohon, para pengamat Pemohon dan para ahli yang diajukan oleh MK, yakni bahwa ketetapan Pasal 55 ayat (2) UU 21/2008 bersinggunan dengan Pasal 55 ayat (1) UU 21/2008 dan Pasal 28D ayat (1) UUD 1945, sehingga memicu ketidaktetapan hukum dalam UU 21/2008 mengenai Perbankan Syariah.

Penilaian selanjutnya, seperti yang disampaikan oleh utusan Pemerintah dan anggota DPR, yakni bahwa ketetapan Pasal 55 ayat (2) UU 21/2008 dilaksanakan dengan mengacu pada asas kebebasan berkontrak, dengan demikian berarti memberi kedua belah pihak dalam menentukan pilihan. Dengan demikian, ketetapan pasal ini tidak bertentangan dengan Pasal 28D ayat (1) UUD 1945 dan karenanya memiliki kepastian hukum.

\section{Reformulasi Pengaturan Penyelesaian Sengketa Perbankan Sejalan Hukum Islam Berdasarkan Teori Kepastian Hukum}

Perbankan syari'ah harus menjadi bagian integral dari upaya restrukturisasi perbankan yang bertujuan untuk meningkatkan ketahanan perekonomian nasional. Krisis telah membuktikan bahwa

\footnotetext{
33 Sarudi Sarudi, "INDONESIA SEBAGAI NEGARA HUKUM," Widya Sandhi: Jurnal
} Kajian Agama, Sosial Dan Budaya, 2021, https://doi.org/10.53977/ws.v0i0.290. 
bank yang beroperasi dengan dasar syariah relatif dapat bertahan dalam menghadapi fluktuasi nilai tukar dan suku bunga yang tinggi. Fakta ini didukung oleh karakteristik kinerja bank syariah yang melarang bunga (riba), transaksi yang tidak transparan (garar) dan spekulatif (maysir).

Untuk membantu terciptanya sistem perbankan nasional yang optimal, perlu dilaksanakan pemberdayaan seluruh kemampuan perbankan Indonesia, termasuk bank yang beroperasi berdasarkan hukum Syariah. Dengan meningkatnya perbankan syariah dan meningkatnya instansi keuangan syariah lainnya, maka perlu diatur kegiatan operasionalnya agar bersifat komprehensif, nyata dan mengandung kepastian hukum. Dengan dukungan UU dan peraturan untuk instansi keuangan Islam di Indonesia, juga mempertahankan model hubungan yang kuat antara instansi keuangan Islam dan klien, berdasarkan keinginan untuk menegakkan sistem Syari'ah.

Pada dasarnya, setiap kontrak yang diciptakan oleh para pihak harus dilaksanakan secara sukarela atau dengan itikad baik. Dalam hal ini akad disebut juga dengan akad atau akad, yaitu bertemunya ijab kabul yang diserahkan oleh satu diantara pihak, dengan penerimaan yang diserahkan oleh pihak lain secara sah sejalan dengan syariat, dan mempunyai akibat atas objeknya. Dalam pengaplikasian akad di instansi keuangan syariah seringkali terjadi perbedaan pandangan baik dalam penafsiran maupun pengaplikasian isi perjanjian.

Perselisihan harus segera diprediksi untuk menemukan penanggulangan bagi Instansi Keuangan Islam dan kliennya. Untuk mengantisipasi sengketa ekonomi syariah yang terjadi di instansi keuangan syariah, baik khalayak maupun instansi keuangan syaariah, bank dan organisasi non-perbankan, serta pengguna jasanya, memahami bahwa mereka tidak dapat mengandalkan pengadilan umum jika mereka benar-benar ingin menegakkan dasar syariah. ${ }^{34}$

Pada masa Reformasi, perselisihan ekonomi yang berkaitan dengan Syariah diselesaikan oleh Majelis Arbitrase Indonesia

\footnotetext{
${ }^{34}$ Fitrianur Syarif, "Perkembangan Hukum Ekonomi Syariah Di Indonesia," PLENO JURE, 2019, https://doi.org/10.37541/plenojure.v8i2.38.
} 
Implikasi Hukum bagi Nasabah Perbankan Syariah yang Beragama Islam dalam Menyelesaikan Sengketa di Pengadilan Negeri

Muamalat, sekarang dikenal sebagai Dewan Arbitrase Syariah Nasional (Basyarnas), yang dibentuk bersama oleh Kejaksaan Agung Republik Indonesia dan Majelis Ulama Indonesia. ${ }^{35}$

Penjabaran Pasal 59 Ayat (1) Yang dimaksud dengan "arbitrase" dalam ketetapan ini termasuk juga arbitrase syariah. Ketetapan Pasal 55 ayat (2) Undang Undang Republik Indonesia Nomor 21 Tahun 2008 Mengenai Perbankan Syariah dan Pasal 59 UU Republik Indonesia Nomor 48 Tahun 2009 Terkait dengan kekuasaan kehakiman, dan penjabarannya menampilkan bahwa telah terjadi penurunan kompetensi peradilan agama di bidang perbankan syariah. Dengan demikian, dapat kita simpulkan bahwa penyelesaian sengketa ekonomi Islam dapat dilaksanakan dengan dua cara, yaitu melalui proses pengadilan dan tanpa proses pengadilan.

Dalam teori kepastian hukum terdapat 2 (dua) pengertian, yaitu: pertama, yaitu terdapat peraturan umum yang harus diketahui mengenai apa yang boleh dan tidak boleh dilaksanakan, dan kedua, berupa perlindungan hukum atas individu dari kesewenangwenangan pemerintah sehubungan dengan terdapat norma hukum yang bersifat hukum. Secara umum, orang mungkin tahu apa yang dapat dibebankan atau dilaksanakan oleh pemerintah atas individu. Kepastian hukum tidak hanya terletak pada bentuk pasal-pasal dalam UU, tetapi juga pada konsistensi putusan hakim antara putusan hakim yang satu dengan putusan hakim lain dalam konflik sejenis yang telah diselesaikan. ${ }^{36}$

Asas kepastian hukum mensyaratkan peraturan yang harus dihormati harus memuat kata-kata peraturan yang benar, maksudnya peraturan tidak dapat diubah tanpa aturan transisi serta tidak dapat diterapkan tanpa alas an. ${ }^{37}$ Teori ini diterapkan untuk

35 Ummi Uzma, "PELAKSANAAN ATAU EKSEKUSI PUTUSAN BADAN ARBITRASE SYARIAH NASIONAL (BASYARNAS) SEBAGAI KEWENANGAN PENGADILAN AGAMA," Jurnal Hukum \& Pembangunan, 2017, https://doi.org/10.21143/jhp.vol43.no3.1496.

${ }^{36}$ Suteki dan Galang Taufani, "Metodologi Penelitian Hukum," Metodologi Penelitian Hukum, 2018.

${ }^{37}$ Haposan Siallagan and Efik Yusdiansyah, Ilmu Perundang-Undangan Di Indonesia (Medan: UHN Press, 2008). 
menganalisis isi pasal-pasal UU Perbankan Syariah yang bertentangan antara pasal satu dengan pasal yang lainnya.

Putusan Hakim Konstitusi dalam Putusan Nomor 93/PUUX/2012 yang membatalkan penjabaran Pasal 55 ayat (2) UU Nomor 21 Tahun 2008 mengenai Perbankan Syariah, yang mengatur pemilihan sengketa antara nasabah dan bank. Penjabaran tersebut memanfaatkan dualisme dalam menangani sengketa di perbankan syariah, sehingga dapat membuat ketidaktetapan hukum dalam menangani sengketa yang timbul di perbankan syariah. Mahkamah Konstitusi berpandangan bahwa pembahasan yang sah diatur oleh penjabaran Pasal 55 ayat (2) UU Perbankan Syariah dalam kasuskasus tertentu yang memicu ketidaktetapan hukum yang dapat merugikan nasabah dan Unit Usaha Syariah (UUS). ${ }^{38}$ Keputusan mengenai bagaimana menangani sengketa perbankan syariah dalam jangka panjang menyebabkan duplikasi badan pengambilan keputusan dengan ketetapan Pasal 49 huruf I UU Nomor 3 Tahun 2006 mengenai Pengadilan agama menegaskan bahwa pengadilan agama dimungkinkan untuk memutuskan sengketa perbankan syariah, termasuk problematika keuangan syariah. Sehingga dapat diketahui bahwa dasar pencabutan Pasal 55 ayat (2) UU Nomor 21 Tahun 2008 mengenai Perbankan Syariah yakni dengan alasan:

1. Terdapat penyimpangan dalam rencana penyelesaian Inkonsistensi tercermin dalam Pasal 55 ayat (1) dan ayat (2) UU Nomor 21 Tahun 2008 mengenai Perbankan Syariah, sehingga terjadi tumpang tindih kewenangan antara pengadilan agama dan pengadilan negeri.

2. Munculnya ketidaktetapan hukum yang tumpang tindih antara dan pengadilan agama dan pengadian negeri membuat ketidaktetapan hukum dalam menangani sengketa perbankan syariah. Tidak konsistennya Pasal 55 ayat (1) dan (2) seperti halnya pasal tersebut memicu terdapat ketidaktetapan hukum bagi nasabah bank syariah untuk menangani sengketa.

3. Hilangnya hak-hak kostitusional nasabah dalam Pasal 55 mengakibatkan nasabah tidak mendapatkan

\footnotetext{
38 Khusairi, “Hukum Perbankan Syariah.”
} 
Implikasi Hukum bagi Nasabah Perbankan Syariah yang Beragama Islam dalam Menyelesaikan Sengketa di Pengadilan Negeri

kepastian hukum untuk menangani persoalannya dengan bank syariah, hal ini menyalahi hak kostitusional yang telah ditetapkan, seperti halnya diatur dalam Pasal 28D ayat (1) UUD 1945 yang menjabarkan bahwa setiap orang berhak atas pengakuan, jaminan, perlindungan, dan kepastian hukum yang adil serta perlakuan yang sama di hadapan hukum.

4. Menurut teori kepastian hukum, tujuan hukum yakni untuk melindungi khalayak. Hukum harus dan harus dipatuhi. Semua orang berharap UU itu bisa disahkan dalam hal peristiwa tertentu. Bagaimana hukum diterapkan sebenarnya tidak boleh menyimpang dari fiat justitia et pereat mundus. Hukum dimaksudkan untuk menciptakan kepastian hukum karena bertujuan untuk menjaga ketertiban umum 39 . Ronald Dworkin mengemukakan bahwa: "Law as it is written in the books and law as it is decided by the judge through judicial process (hukum yakni apa yang tertulis di dalam buku maupun yang diputuskan oleh hakim melalui proses pengadilan). ${ }^{40}$

Oleh karena itu, jika dikaitkan dengan ketetapan klarifikasi ayat (2) Pasal 55 terdapat dualisme instansi penyelesaian sengketa ekonomi syariah, di satu pihak diserahkan sepenuhnya kepada pengadilan agama (pasal 55 ayat (1)) UU Perbankan Syariah), tetapi di sisi lain, ketetapan penyelesaian di pengadilan umum dibuka (ayat (2) Pasal 55). Hasil analisis hukum bahwa ayat (2) Pasal 55 UU Nomor 21 Tahun 2008 mengenai Bank Umum Sejalan hukum islam bertentangan dengan UU Nomor 3 Tahun 2006 mengenai Peradilan Agama.

Ayat (2) Pasal 55 dipandang bertentangan dengan peraturan UU Nomor 3 Tahun 2006 mengenai Peradilan Agama, oleh karena itu, jika akad (kesepakatan) yang diciptakan oleh para pihak bertentangan dengan UU. hasilnya tidak sah dan batal. Pilihan yang diambil oleh hakim Pengadilan memenuhi prasyarat untuk berlakunya asas kepastian hukum, khususnya dengan

\footnotetext{
${ }^{39}$ Sudikno Mertokusumo and A Pitlo, Bab-Bab Tentang Penemuan Hukum (Bandung: Citra Aditya Bakti, 1993).

40 Nasution, “Metode Penelitian Hukum Normatif Dan Perbandingan Hukum."
} 
menyerahkan putusan, kepastian hukum untuk khalayak akan terjamin. Khalayak memahami apa yang harus mereka hormati dalam hubungan yang sah di antara mereka dan apa yang dapat mereka prediksi dari otoritas publik. Pilihan yang diambil oleh Hakim MK dalam membatalkan klarifikasi Pasal 55 ayat (2) UU Perbankan Syariah telah menutup ruang bagi pemberian pembelaan yang pada akhirnya dapat menjamin kepastian hukum yang dapat membatasi kerugian bagi nasabah maupun bagi perbankan syariah.

Kekuatan hukum akad dengan bank syariah yang menangani sengketa melalui pengadilan negeri dipertegas dengan ketetapan ayat (2) dan (3) Pasal 55 UU No. 21 Tahun 2008 setelah Putusan Mahkamah Konstitusi No. 93/PUU-X/2012 untuk penyelesaian sengketa usaha dan keuangan syariah di luar perbankan dapat dilaksanakan antara lain dengan menerapkan metode pengungkapan hukum yang ada untuk memastikan bahwa keputusan tersebut sah dan dapat dilaksanakan bagi instansi yang bersangkutan.

Seperti yang ditunjukkan oleh penulis, metode yang dapat digunakan yakni strategi argumentasi berupa argumentasi a fortiori, yaitu teknik hubungan yang menumbuhkan sejauh mana dasar-dasar yang ada untuk kemudian diterapkan pada kesempatan yang komparatif, sebanding atau serupa. Strategi pengungkapan yang sah ini direncanakan untuk menjabarkan sifat yang lebih umum dari peristiwa hukum ${ }^{41}$. Perbankan syariah yakni bagian dari ekonomi Islam dan oleh karena itu ada entitas bersama di antara mereka, yang diatur oleh hukum Sejalan hukum islam. Putusan Mahkamah Konstitusi No. 93/PUU-X/2012 sebenarnya merupakan bagian dari praktik penegakan hukum yang menyerahkan penegasan kompetensi untuk mengeluarkan putusan di pengadilan agama di bidang ekonomi syariah. Dengan demikian, putusan ini meluas ke perselisihan dalam bisnis Islam dan instansi keuangan di luar perbankan syariah. Ini berarti bahwa klausul dalam kontrak antara klien dan bisnis Islam dan instansi keuangan bertentangan dengan hukum dalam mendirikan pengadilan yurisdiksi umum untuk menangani setiap perselisihan yang mungkin timbul. Hakim

\footnotetext{
41 Titin Samsudin, "Peranan Hakim Dalam Penemuan Hukum," Al-Mizan 10, no. 1
} (2014). 
Implikasi Hukum bagi Nasabah Perbankan Syariah yang Beragama Islam dalam Menyelesaikan Sengketa di Pengadilan Negeri

pengadilan distrik harus mengabaikan perselisihan komersial dan keuangan syariah, bahkan jika para pihak setuju.

\section{Penutup}

Implikasi hukum bagi nasabah perbankan syariah dalam menangani sengketa perbankan syariah di Pengadilan Negeri terdiri dari implikasi Putusan Mahkamah Konstitusi Nomor 93/PUUX/2012 yang menimbulkan kekosongan hukum (vacumrecht) dan norma kabur, hal ini mengakibatkan ketidakteptan hukum dalam menangani sengketa perbankan syariah. Hal ini dapat menguatkan eksistensi dan kedudukan Peradilan Agama dalam penyelesaian sengketa perbankan syariah dan menutup jalan dalam penyelesaian sengketa perbankan syariah melalui Peradilan Umum.

Susuan peraturan baru mengenai penyelesaian sengketa perbankan syariah berdasarkan teori kepastian hukum, berkaitan dengan kekuatan hukum kontrak dengan bank syariah yang kesepakatannya berisi penyelesaian sengketa melalui peradilan umum, sebagaimana ketentuan ayat (2) dan ayat (3) Pasal 55 UU No. 21 Tahun 2008 setelah Putusan Mahkamah Konstitusi Nomor 93/PUU-X/2012 bahwa penyelesaian sengketa perbankan syariah berdasarkan isi perjanjian, sebagai suatu aturan, mengubah posisi forum penyelesaian sengketa yang sebelumnya ditunjuk oleh Pengadilan Negeri kemudian beralih ke Pengadilan Agama dan Badan Arbitrase Syariah Nasional (Basyarnas). Selanjutnya kepastian hukum ayat (2) Pasal 55 diperkirakan bertentangan dengan pengaturan UU No. 3 Tahun 2006 mengenai Peradilan Agama, yang menyatakan apabila akad (kesepakatan) dilaksanakan oleh para pihak berlawanan dengan hukum, hasilnya adalah tidak sah. Pilihan yang diambil oleh hakim pengadilan memenuhi prasyarat untuk berlakunya asas kepastian hukum yang sah.

\section{Daftar Pustaka}

Andrianto, Fadly. "Kepastian Hukum Dalam Politik Hukum Di Indonesia." Administrative Law and Governance Journal, 2020. https://doi.org/10.14710/alj.v3i1.114-123.

Antonio, M. S. I. Bank Syariah: Dari Teori Ke Praktik. Jakarta: Gema Insani, 2001.

Benuf, Kornelius, and Muhamad Azhar. "Metodologi Penelitian Hukum Sebagai Instrumen Mengurai Permasalahan Hukum 
Kontemporer." Jurnal Gema Keadilan 3, no. 2 (2019): 145-60.

Efendi, Jonaed. Kamus Istilah Hukum Populer. Cet. Ke-I, Jakarta, Predana Media Group, 2016.

Efendi, Jonaedi, and Johnny Ibrahim. Metode Penelitian Hukum Normatif Dan Empiris. Kencana, 2018.

Fachryana, Fikri Al-Haq. "Manajemen Risiko Strategis Bank Syariah." Jurnal Manajemen, Ekonomi, Keuangan Dan Akuntansi, 2020.

Febriyani, Dian, and Ida Mursidah. "Ekonomi Dan Perbankan Syariah Di Tengah Era Digital." Hukum Ekonomi Syariah, 2020.

Halim, Manduh M. Hanafi dan Abdul. "Tujuan Analisis Laporan Keuangan." Analisis Laporan Keuangan, 2016.

Isnaeni, A M. "Standar Hukum Sistem Syariah Pada Lembaga Keuangan Bukan Bank Dalam Bentuk Asuransi Syariah." Jurnal Unizar Law Review, 2019.

Karsayuda, M. Rifqinizamy. "Politik Hukum Nasional Legislasi Hukum Ekonomi Syariah." Journal de Jure, 2016. https://doi.org/10.18860/j-fsh.v7i1.3510.

Kencanawati, E. "POLITIK HUKUM TERHADAP PENYELESAIAN SENGKETA EKONOMI SYARIAH DALAM PEMBANGUNAN HUKUM NASIONAL INDONESIA." Jurnal Paradigma Hukum Pembangunan, 2017.

Khusairi, Halil. "Hukum Perbankan Syariah." Al-Qisthu: Jurnal Kajian Ilmu-Ilmu Hukum, 2015. https:/ / doi.org/10.32694/010120.

Mardani. Aspek Hukum Lembaga Keuangan Syariah Di Indonesia. Kencana, 2017.

Marni, Asdi, Edi Darmawijaya, and Faisal Fauzan. "Jurnal Kajian Ilmu Hukum Dan Syariah." Jurnal PETITA, 2018.

Mertokusumo, Sudikno, and A Pitlo. Bab-Bab Tentang Penemuan Hukum. Bandung: Citra Aditya Bakti, 1993.

Nasution, Bismar. "Metode Penelitian Hukum Normatif Dan Perbandingan Hukum." In Dialog Interaktif Tentang Penelitian Hukum Dan Hasil Penulisan Hukum Pada Majalah Akreditasi. Fakultas Hukum Universitas Sumatera Utara, Medan, 2003.

NASUTION, ZUBAIDAH, and SHOLIKHA OKTAVI. "ANALISIS FAKTOR-FAKTOR YANG MEMPENGARUHI KINERJA KEUANGAN PERBANKAN DI INDONESIA." JURNAL MASHARIF AL-SYARIAH, 2016.

Peraturan Bank Indonesia Nomor 9/19/PBI/2007 (n.d.). 
Implikasi Hukum bagi Nasabah Perbankan Syariah yang Beragama Islam dalam Menyelesaikan Sengketa di Pengadilan Negeri

Prihadi, Toto. "Analisis Laporan Keuangan." In Analisis Laporan Keuangan, 2020.

Putusan Mahkamah Konstitusi Nomor 93/PUU-X/2012 (n.d.).

Samsudin, Titin. "Peranan Hakim Dalam Penemuan Hukum." AlMizan 10, no. 1 (2014).

Sarudi, Sarudi. "INDONESIA SEBAGAI NEGARA HUKUM." Widya Sandhi: Jurnal Kajian Agama, Sosial Dan Budaya, 2021. https://doi.org/10.53977/ws.v0i0.290.

Shandy Utama, Andrew. "PERKEMBANGAN PERBANKAN SYARIAH DI INDONESIA." UNES Law Review, 2020. https://doi.org/10.31933/unesrev.v2i3.121.

Siallagan, Haposan, and Efik Yusdiansyah. Ilmu Perundang-Undangan Di Indonesia. Medan: UHN Press, 2008.

Suteki dan Galang Taufani. "Metodologi Penelitian Hukum." Metodologi Penelitian Hukum, 2018.

Syafii, Indra, and Isnaini Harahap. "Peluang Perbankan Syariah Di Indonesia." Seminar Nasional Teknologi Komputer $\mathcal{E}$ Sains (SAINTEKS), 2020.

Syarif, Fitrianur. "Perkembangan Hukum Ekonomi Syariah Di Indonesia." PLENO JURE, 2019. https://doi.org/10.37541/plenojure.v8i2.38.

"Undang-Undang Nomor 21 Tahun 2008 Tentang Perbankan Syariah," n.d.

“Undang-Undang Republik Indonesia Nomor 3 Tahun 2006 Tentang Perubahan Atas Undang-Undang Nomor 7 Tahun 1989 Tentang Peradilan Agama," n.d.

UNDANG-UNDANG REPUBLIK INDONESIA NOMOR 30 TAHUN 1999 TENTANG ARBITRASE DAN ALTERNATIF PENYELESAIAN SENGKETA (n.d.).

“Undang Undang Dasar Negara Republik Indonesia Tahun 1945," n.d.

UU No. 50 Tahun 2009 tentang Perubahan Kedua atas UndangUndang Nomor 7 Tahun 1989 tentang Peradilan Agama (n.d.).

UU Nomor 10 Tahun 1998. “Undang-Undang Republik Indonesia Nomor 7 Tahun 1992 Tentang Perbankan Sebagaimana Telah Diubah Dengan Undang-Undang Nomor 10 Tahun 1998." Bank Indonesia, 1998.

Uzma, Ummi. "PELAKSANAAN ATAU EKSEKUSI PUTUSAN 
BADAN ARBITRASE SYARIAH NASIONAL (BASYARNAS) SEBAGAI KEWENANGAN PENGADILAN AGAMA." Jurnal Hukum $\mathcal{E}$ Pembangunan, 2017. https://doi.org/10.21143/jhp.vol43.no3.1496.

Warka, Made, and Erie Hariyanto. "Kedudukan Bank Syariah Dalam Sistem Perbankan Di Indonesia." IQTISHADIA: Jurnal Ekonomi $\mathcal{E} \quad$ Perbankan Syariah, 2016. https:/ / doi.org/10.19105/iqtishadia.v3i2.1076. 